UCRL-ID-123447

\title{
Incident Analysis Report
}

\author{
David W. Gregg, Al Buerer, and Steve Leeds
}

February 20, 1996

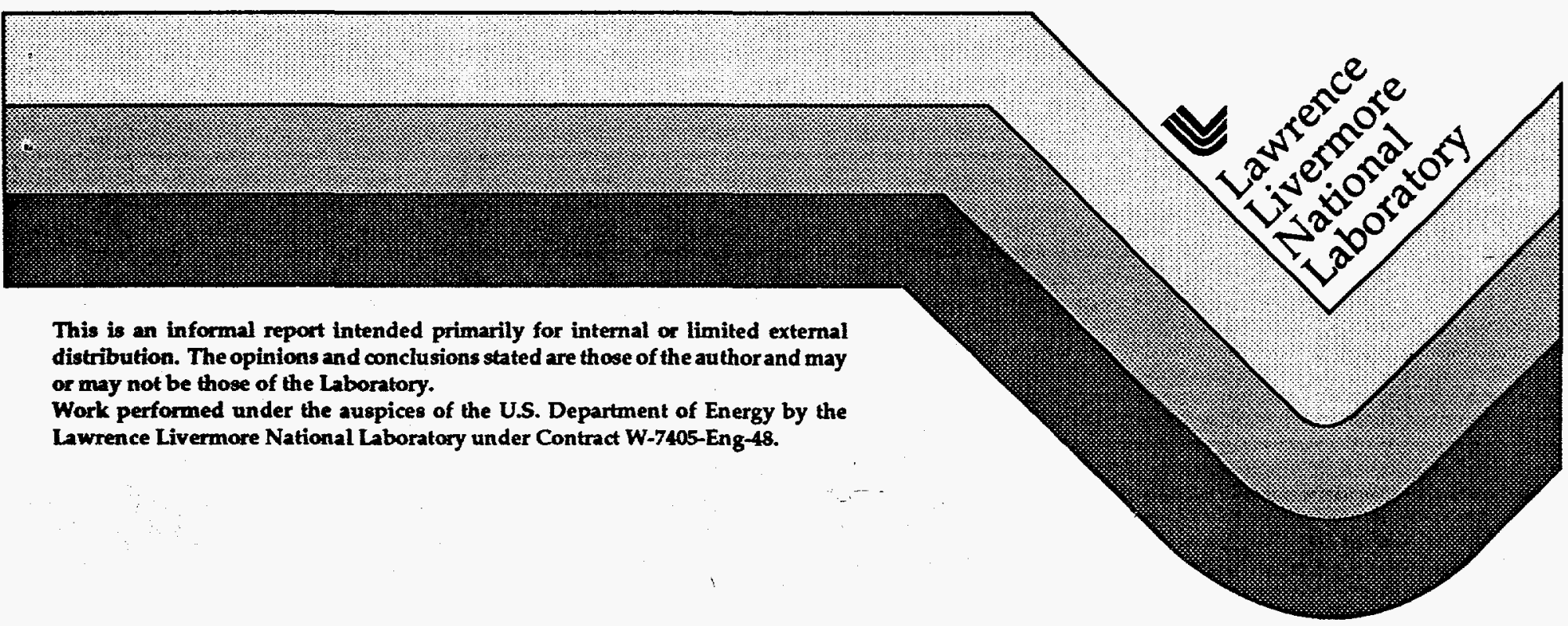




\section{DISCLAMER}

This document was prepared as an account of work sponsored by an agency of the United States Government. Neither the United States Government nor the University of California nor any of their employees, makes any warranty, express or implied, or assumes any legal liability or responsibility for the accuracy, completeness, or usefulness of any information, apparatus, product, or process disclosed, or represents that its use would not infringe privately owned rights. Reference herein to any specific commercial product, process, or service by trade name, trademark, manufacturer, or otherwise, does not necessarily constitute or imply its endorsement, recommendation, or favoring by the United States Government or the University of California. The views and opinions of authors expressed herein do not necessarily state or reflect those of the United States Government or the University of California, and shall not be used for advertising or product endorsement purposes.

This report has been reproduced directly from the best available copy.

Available to DOE and DOE contractors from the Office of Scientific and Technical Information P.O. Box 62, Oak Ridge, TN 37831

Prices available from (615) 576-8401, FTS 626-8401

Available to the public from the National Technical Information Service

U.S. Department of Commerce 5285 Port Royal Rd., Springfield, VA 22161 
INCIDENT ANALYSIS REPORT

\section{A. SUMMARY}

1. SHORT DESCRIPTION:

2. TYPE:

3. DATE:

4. TIME:

5. LOCATION:

6. DEPARTMENTS INVOLVED:

\section{INJURY/ILLNESS:}

8. HAZARDOUS MATERIALS:

9. PROPERTY DAMAGE:
Report Date 2/20/96

Serial No. 0496

Chemical Fire in Building

$1 / 19 / 96$

0820 hrs.

B-431, R-1309

Electrical Engineering Department, Defense Sciences

Electrical Engineering Division

Magnetic Fusion Energy Department, M Division

None

$100 \%$ Fuming Nitric Acid

$\$ 5,000$

\section{B. Information}

\section{B.1 The Incident}

A modest size fire occurred on Friday morning, January 19, 1996, at $0820 \mathrm{hrs}$. in a microwave laboratory (Room 1309) in Building 431. This fire originated in a metal storage cabinet containing industrial chemicals in the corner of the room and was controlled by the buildings automatic fire sprinkler system. Final extinguishment was affected a few minutes later by the Laboratory Fire Department. There was no lost time injury although four Laboratory employees were evaluated by Health Services and released to return to work. Total damage is initially estimated at a few thousand dollars, mostly due to water damage. This was reported as an Off-Normal Occurrence.

\section{B.2 Technical Background}

\section{B.2.1 The Chemical}

The chemical identified as causing the fire is $100 \%$ fuming nitric acid. Ten individual liter bottles of $100 \%$ fuming nitric acid were ordered from Fluka Chemical Corporation, $980 \mathrm{~S}$. Second Street, Ronkonkoma, NY, and were shipped to LLNL two to three months before the fire. Each bottle was packaged individually. Fluka said that each bottle was put in an inert plastic bag and then enclosed in its own metal "paint" can surrounded with vermiculite. This would protect the glass bottles from being broken during shipment, and provide two layers of inert packaging, thus meeting DOT shipping regulations. The can was put in a fiberboard box for shipment.

When the ten individual boxes were received, the experiment was not ready to use the material, so the unopened boxes were put in a cabinet by themselves as directed by the scientist who had ordered the material. Both the physicist who ordered the acid and his mechanical technician knew that it would be prudent to store such a strong oxidizer by itself and certainly separate from combustibles. However, they made the mistake of presuming it would be safe to store the acid in the same packaged form that was deemed safe for shipment. 
It is classified as UN2031 Inhalation Poison, Zone B Group 1. Special packing requirements. The MSDS identifies the hazards as being: Oxidizing, highly toxic, contact with combustible material may cause fire, causes burns, reacts violently with water.

An LLNL chemist experienced with synthesizing and using $100 \%$ fuming nitric acid stated to this Incident Analysis Committee that the acid always built up pressure in closed bottles at room temperature. When the acid was stored in Teflon bottles, they would exhibit considerable bulging out after standing at room temperature for no more than one day. He believes it was due to the spontaneous decomposition of the acid. This could be avoided by storage at $0 \mathrm{C}$, but the acid would turn yellow in a couple of months indicating that the decomposition reaction was still progressing, although much more slowly. Storage at -80 $\mathrm{C}$ was sufficient to prevent any detectable decomposition. When the concentration is lowered to $98.5 \%$, by spontaneous decomposition or dilution with water, the fuming nitric acid appeared to be quite stable and did not exhibit pressure buildup in a closed bottle at room temperature.

This experience is consistent with that reported by John D. Clark in his book "Ignition!, An Informal History of Liquid Rocket Propellants." He reports that for years people had noted that a standing drum of white fuming nitric acid (WFNA) slowly built up of pressure, and had to be vented periodically. They had assumed this to be a by-product of drum corrosion. However, upon further investigation, they concluded that the acid was inherently unstable, and would decompose spontaneously, all by itself, producing the gas pressure.

\section{B.2.2 Room 1309}

Room 1309 is a ground floor, exterior room attached to Building 431. It has a concrete pad floor and an automatic fire sprinkler system. It was used as a microwave laboratory until the fire. The chemicals were stored there in metal cabinets only as a temporary measure.

\section{B.3 Procedural Background}

The Facility Safety Procedure was not updated to address the chemicals stored in room 1309 because it was anticipated that they would be transferred to the planned chemistry building when the new funding arrived, which was anticipated to be imminently. Unfortunately, the funding was delayed and then finally canceled, just after the fire.

\section{B.4 Supervision}

Employee A, a mechanical technician, at the direction of his supervisor, employee B, a physicist, placed the ten containers of fuming nitric acid still in their shipping boxes, in a metal cabinet in room 1309 for temporary storage before being moved to the planned experimental area owned by the Chemistry Department which was well equipped to handle it safely.

\section{B.6 Employee's "A" \& "B"}

" $A$ " is a mechanical technician with some training and experience in handling hazardous chemicals. " $\mathrm{B}$ " is a physicist with moderate experience in the handling of hazardous chemicals. 


\section{B.7. Previous Incidents}

Fuming nitric acid at lower concentrations is commonly ordered by LLNL and handled without creating fires. However, it is extremely rare for LLNL to order it at a concentration as high as $100 \%$. Approximately twelve years ago another LLNL experiment required $100 \%$ fuming nitric acid and ordered some, which had to be specially made by a vendor. It was shipped by the vendor with a similar outer package made of fiberboard. The order was sent in two separate shipments at almost the same time. For one shipment, the truck caught fire in route and was totally destroyed. It wasn't clear that the acid was implicated in the cause of the fire. The other shipment caught fire at the LLNL receiving dock, clearly due to the acid. With this unexpected result, the experimenters decided to take more precautions with the next order. They ordered the far safer $98.5 \%$ fuming nitric acid, from a different vendor, and had it shipped in an aluminum drum (inert to this concentration of the acid) by itself in a refrigerated truck. No further incidents occurred with the acid in this set of experiments.

It appears that the LLNL experience is three incidents for three shipments. Of the three times the $100 \%$ acid was shipped to LLNL it resulted in a spontaneous ignition every time. In all three cases it was shipped in glass bottles packaged in a fiberboard boxes.

\section{Team Comments}

Both " $\mathrm{A}$ " and " $\mathrm{B}$ " recognized the need to store the acid in a cabinet by itself, separate from combustibles. However, neither seemed to recognize the combustible hazard of the fiberboard shipping boxes. They were blinded by the assumption that DOT regulations for safe shipment would also meet safe storage requirements. This was the primary mistake. It not only placed a strong oxidizer in the same cabinet with a fuel, but created ideal conditions for spontaneous ignition even in the event of a very slow leak. Fiberboard boxes packed side-by-side in a cabinet would provide good thermal insulation. A slow leak of liquid acid or N2O5 gas (and other oxides of nitrogen) would react slowly with the fiberboard generating heat. Due to the thermal insulation, the heat would not conduct away easily. Thus, the temperature would gradually rise until the ignition temperature is reached. At this point the supply of air oxygen would be sufficient to support a flame. Once a flame started, the increased temperature would very likely cause the remainder of the bottles of acid to fracture, further accelerating the flame.

It is also possible that a more catastrophic initiating event took place. As discussed above, pressure buildup due to spontaneous acid decomposition would be expected at temperatures above $0 \mathrm{C}$. (The MSDS for $90 \%$ fuming nitric acid states that pressure may gradually buildup in the bottle and recommends unscrewing the cap periodically to release it. However, the MSDS supplied for the $100 \%$ material makes no mention of the possibility of such a pressure buildup.) Due to the small air space over the liquid in the bottles, a chemical reaction releasing even a small amount of gas could easily raise the pressure significantly. The pressure could have built up sufficiently to blow the cap off or fracture the bottle. Due to the small gas volume, this would not have been a very energetic event. However, it would certainly release the liquid and may have torn the plastic bag around the bottle. If the lid of the surrounding can was not blown off, the liquid acid could still corrode through the can and seep to the fiberboard box, initiating the spontaneous combustion sequence.

The committee believes that the most likely sequence involved the pressure buildup and fracturing of the bottle. However, in either case, the subsequent fire would not have occurred if the acid had been removed from the fiberboard boxes and stored in a cabinet separate from any combustibles. 


\section{ADDITIONAL BACKGROUND}

D.1. Technician A reported that the fiberboard boxes had no warning labels other than corrosive.

D.2. According to Hazardous Waste Management, the shipping container as described meets DOT regulations.

D.3. Phone Conversation with Maryanne Holmes at the vendor, Fluka Chemical Corp.:

a) Fluka keeps it stored in a room without incident.

b) She knows of no other fires caused by the chemical.

c) She described how it was packaged for shipment.

D.4. Adjacent lockers in room 1309 contained flammable materials which were also being stored temporarily for the same experiments.

D.5. The locker immediately next to it contained $1 \mathrm{Kg}$ of Guanidine Nitrate, which can decompose explosively when heated.

\section{E. JUDGMENT OF NEEDS}

E.1. The potential hazards are sufficient to recommend that $100 \%$ nitric acid be handled as a restricted item, requiring $\mathrm{HC}$ signature prior to purchase. This would give the Industrial Hygienists a chance to talk with the experimenter about special precautions needed for this chemical.

E.2. For future orders:

a) Shipments of fuming nitric acid at concentrations above $98.5 \%$ should be refrigerated to approximately $0 \mathrm{C}$ or below to prevent the possibility of pressure buildup in the containers during transit.

b) The outer shipping container should be specified as a nonflammable material and all packing material should be nonflammable. It is unacceptable to ship it to LLNL in fiberboard boxes as the outermost container.

c) Unpack the $100 \%$ fuming nitric acid upon delivery and store it in refrigerated storage at $0 \mathrm{C}$ or below. When in use at room temperature in a fume hood, the caps should be loosened slightly to prevent pressure buildup.

d) Secondary containment should also be provided by placing the bottles in a nonreactive tray to contain leaks. According to an EPD chemist, a polyethylene tray will not combust and would be a satisfactory material for the containment tray.

E.3. Facility management should evaluate continued storage of the chemicals in Room 1309 and transfer those to a safer storage area as appropriate. Since the funding for the experiments has been canceled, disposal of the chemicals should be considered.

E.4. If chemical storage is to continue in Room 1309 or elsewhere in building 431, this should be incorporated in the B431 Facility Safety Procedure, which should define appropriate changes needed to insure adequate safety.

E.5. Hazards Control should issue a "Lessons Learned" bulletin.

\section{F. ATTACHMENT}

Photograph of fire site showing metal locker with doors open and open metal cans on floor that formally contained glass bottles of the $100 \%$ fuming nitric acid. 
G. TEAM MEMBERSHIP

Sand Wu frog

Al Buerer

stare Reeds

Steve Leeds

Fire Protection Engineer

Distribution:

Henry Bell

Al Buerer

Steve Leeds 
$=$ 


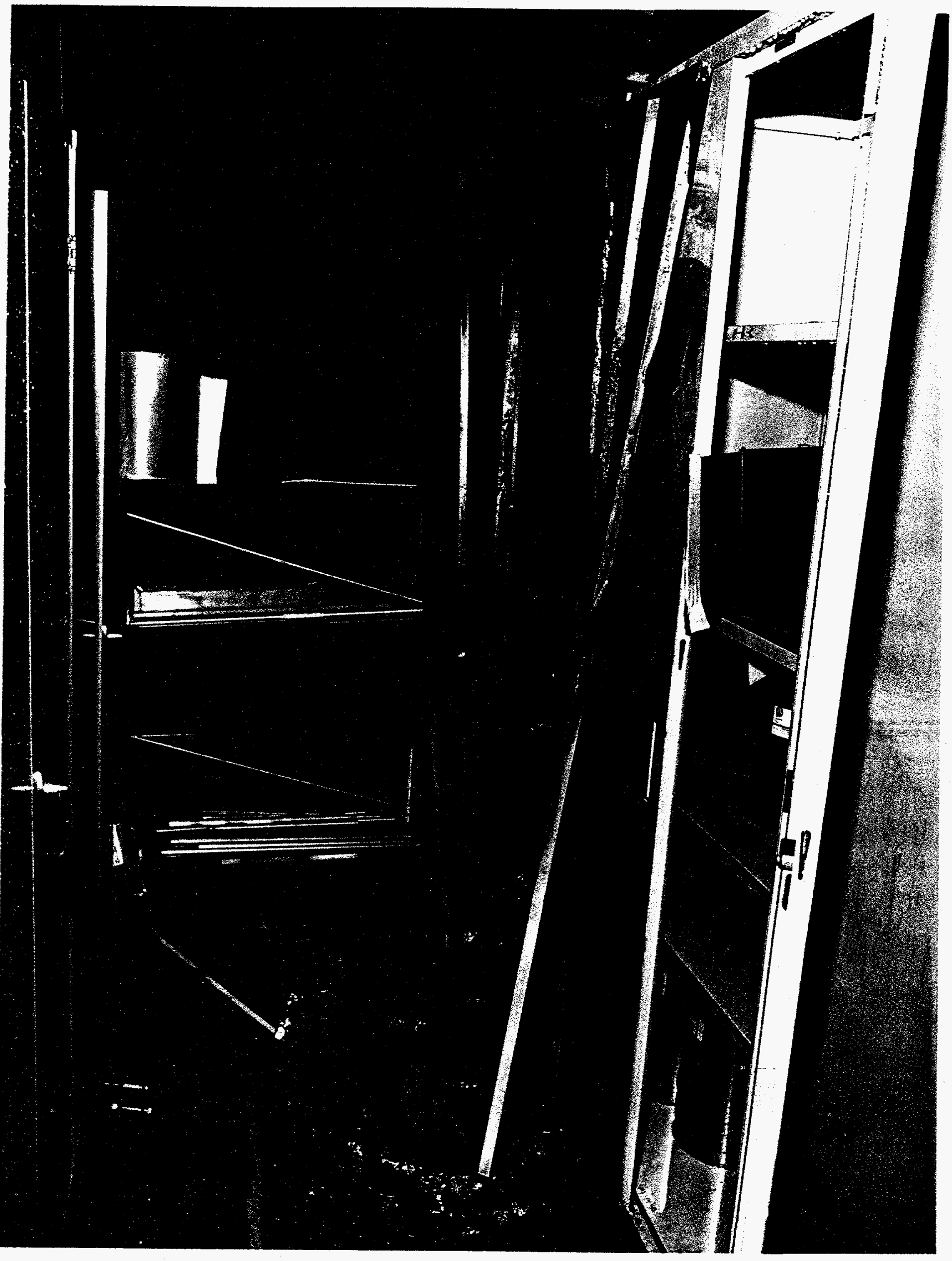




\section{DISCLAMMER}

Portions of this document may be illegible in electronic image products. Images are produced from the best available original document. 
